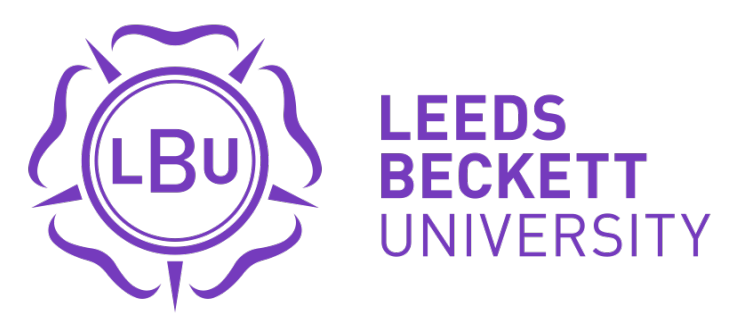

Citation:

Shore, H (2009) 'The reckoning': Disorderly women, informing constables and the Westminster justices, 1727-33. Social History, 34 (4). 409 - $427 . \quad$ ISSN 0307-1022 DOI: https://doi.org/10.1080/03071020903256994

Link to Leeds Beckett Repository record:

https://eprints.leedsbeckett.ac.uk/id/eprint/123/

Document Version:

Article (Accepted Version)

The aim of the Leeds Beckett Repository is to provide open access to our research, as required by funder policies and permitted by publishers and copyright law.

The Leeds Beckett repository holds a wide range of publications, each of which has been checked for copyright and the relevant embargo period has been applied by the Research Services team.

We operate on a standard take-down policy. If you are the author or publisher of an output and you would like it removed from the repository, please contact us and we will investigate on a case-by-case basis.

Each thesis in the repository has been cleared where necessary by the author for third party copyright. If you would like a thesis to be removed from the repository or believe there is an issue with copyright, please contact us on openaccess@leedsbeckett.ac.uk and we will investigate on a case-by-case basis. 
“'The Reckoning': Disorderly Women, Informing Constables and the Westminster Justices, 1727 - 1733,*

The study of criminal prosecution has been the touchstone for a generation of historians who have sought to understand the administration of crime and policing and the interactions between the police and the policed in the eighteenth century metropolis. Given the top-down nature of the sources this work has focused most centrally on the systems that governed the control of crime and disorder rather than the nature of the crime itself. In particular, Douglas Hay's seminal chapter, 'Property, Authority and the Criminal Law', published in 1975, remains a powerful and complex exploration of the ways in which social order was manipulated and ultimately maintained by the rulers of eighteenth century England. Hay demonstrated how the criminal justice system was used to maintain 'bonds of obedience and deference' and to legitimize the status quo. ${ }^{1}$ To do so he focused much of his attention on the social elites and on the complex web of relations and practices with which they controlled the criminal justice system. Hay's argument has not gone unchallenged. Peter King, John Langbein, Thomas Green, Joanne Innes and John Styles have contributed both correction and refinement to Hay's thesis, greatly expanding our knowledge of the legislative process. ${ }^{2}$ King's work has particularly sought to uncover and understand the discretionary elements within the judicial system, 'It remains unclear...precisely which social groups, social interactions, and discursive formulations were decisive in shaping many 
important arenas within the judicial process'. ${ }^{3}$ Whilst this work has analysed those who used the law, why they used the law, and how this was negotiated in the context of eighteenth century social relations, much of it has tended to privilege the interactions of the middling sorts and the elites. The accused and the guilty, the victims and the witnesses, do run through these accounts, however they are inevitably filtered through justice's lens. Whilst we catch sight of the criminal through a series of interactions with justice, most offer only a fleeting glimpse of these negotiations with the criminal justice system. Where the criminal poor have been supposedly at the centre of the stage, plebeian agency is frequently understudy to 'larger' questions of class relations and class struggle. ${ }^{4}$ However, there are some notable exceptions. Peter King has done much to negotiate the experiences of different social groups in the eighteenth century; as have the studies of criminal and plebeian experience found in recent work by Mary Clayton and Tim Hitchcock. ${ }^{5}$ These detailed reconstructions tell us much about the manner in which plebeian Londoners negotiated the criminal justice system, interacted with local law enforcers, and were subjected to sanctions such as the round-house, the House of Correction, transportation, and in some unfortunate cases, the gallows. Other historians have explored eighteenth century criminals by using the gallows confessions and criminal biography, which offer a circumscribed and negotiated version of events and interactions with the criminal justice system. ${ }^{6}$ However, not all criminals were executed and subjected to the attentions of the Ordinary, or attained enough 'merit' to be the subject of a biography. Other 
individuals became 'public' in the sense that their actions and reputation were in the public arena. Mary Harvey was such an individual. Thus between the years 1727 and 1732, she was as much an object of public curiosity as her fellow 'criminals', James Dalton, Mother Needham, and the aristocratic rake, Colonel Charteris. Variously referred to as the 'notorious Moll Harvey' or the 'noted Virago', 'so frequently mentioned in the public prints', Mary's antagonistic relationship with justice, particularly during 1730-31, was arguably well-known to early eighteenth century Londoners.

This article will argue that the 'story' of this disorderly woman casts light on a number of issues. Firstly the events under consideration provide an insight into the interaction between the justice system and plebeian networks, particularly in 1730 and 1731 . In these years the disorderly house campaigns, under the aegis of which Mary Harvey and her confederates were generally charged, involved local Justices, constables, and the local community, both respectable and disorderly. Whilst these campaigns were to be one of the last purges of the early eighteenth century incarnation of the Society for the Reformation of Manners, I will demonstrate that they were equally a targeted attack on specific individuals, in this case Mary Harvey and her Sister Isabella Eaton, both keepers of taverns in the St. James's district. Over a number of years we see the women avoiding conviction, instigating counter-convictions, and negotiating the justice system in order to protect themselves and their livelihoods. Whilst we can only read the lives of Mary and Isabella through the lens of criminal administration, it is possible to tell a story about plebeian 
agency and the social significance of the law. Thus despite the concerted efforts of some powerful justices of the peace, Harvey and Eaton both played the system and fought it. Secondly, this story provides an insight into the nature of criminal networks. Elsewhere I have argued that models of criminal organization in this time, the aftermath of Jonathan Wild's ascendancy, need to be considered in the context of overlapping networks. ${ }^{7}$ Locality and community are hugely important in how we think about these interactions. Community is undoubtedly a problematic term. It suggests a cohesion that is not necessarily evidence in the socially mixed neighbourhood that Mary inhabited. However, reference to 'community' does provide a way of referring to the interconnectedness of different local networks and local relationships that can be traced in these events. In this context, Mary was certainly a member of a community, and this was a community that by the late 1720 s was becoming noisome in the extreme to its more respectable neighbours. By 1730 , this would bring Mary Harvey and Isabella Eaton in particular, to the attention of the Chairman of the Westminster Justices, Sir John Gonson.

In order to tell this story I have drawn on a range of primary sources, principally the Old Bailey Sessions and the London newspapers. Both the advantages and the limitations of the Old Bailey Sessions (and related sources such as the 'Ordinaries' Accounts) have been well rehearsed. ${ }^{8}$ They are an edited record; they did not report every trial held at the Old Bailey, and they tended to privilege trials from which sensation (murder, highway robbery, sexual offences) could be derived. Coverage of the trials became more 
systematic from 1729 , but the proceedings still only provided partial transcripts. Witness testimony was often reduced, and the words of defendants were often omitted. Nevertheless, as Shoemaker (et al) point out in their guide to the sessions, 'the material reported was neither invented nor significantly distorted'. 9 The London press had expanded rapidly from the late seventeenth century. Crime reporting was a key and important element of the printed media. This was not in the form of editorial or headline press. In papers like the Daily Post, the domestic or London news was often on the front page. This was hardly meaningful since the paper was at this time only two sheets and the second sheet consisted largely of advertisements and lists of trade prices.$^{10}$ However, it did mean that reports about criminals were accessible, straight under the news from abroad and reports on the movements of the aristocracy. Although the newspapers were more concerned with reporting series of events rather than conveying any sort of moral message or simply sensational reporting, the focus on particular criminals and/or trials can be read as a form of cultural intervention. Arguably the publishers and journalists, who also shaped the periodical and pamphlet press, directly shaped the public knowledge of 'local' criminals at this time. Whilst the commentary on events needs to be read critically, the 'factual' basis of reports can be tested to some extent by cross-reference with the Middlesex Sessions. ${ }^{11}$ In the cases described in this 
article, the chronologies described by the press did correspond more or less to those found in the Sessions. Many of the events reported by the press can be traced through the Calendars to the Middlesex Sessions. However, the survival of indictments is mixed. Often when indictments have not been found, recognizances or bonds to appear, have survived. A range of other records, such as petitions, affidavits and law reports has also been drawn upon.

\section{Protagonists and Trials}

The main events of this story take place from autumn 1727 to summer 1732 . Mary Harvey, also known as Moll Harvey, alias Philips, alias Mackaig, was to start making regular incursions onto the criminal justice stage from 1727. In December of that year, the Old Bailey was the location for a number of trials at which Harvey and her confederates, Isabella Eaton (her sister) John Eaton (the husband, probably common-law, of Isabella Eaton) and Mary Stanly (alias Stanley alias Sullivan), gave evidence, including the murder trial of Richard Savage, the poet and friend of Samuel Johnson. ${ }^{12}$ In February 1728, our protagonists featured in two trials that marked the start of their public career as a thorn in the sides of the Westminster justices. On 28 February Mary Harvey and John Eaton were tried on two indictments. The first was for the theft of various goods of Jane Fielding. ${ }^{13}$ Their victim had previously been 'acquainted with the prisoners in Bristol' and perhaps because of this, the court was unsympathetic, and resolved that both the prosecutor and prisoners were a 
'contentious and malicious People'. Harvey and her co-defendants were acquitted. ${ }^{14}$ The second trial was that of Harvey and John Eaton for an assault on Henry Wilcox. ${ }^{15}$ Wilcox had been tried for Highway Robbery in December 1727 when John Eaton and Mary Stanly had been prosecution witnesses. ${ }^{16}$ In early 1728 he had received a pardon in order to qualify him to counter prosecute Mary Harvey, John Eaton, and Mary (Isabella) Eaton, for highway robbery. ${ }^{17}$ The jury decided that Wilcox's charge was unjust and acquitted the prisoners. ${ }^{18}$ These early trials introduce several important elements that would recur in the trials of Mary Harvey, Isabella Eaton and their various husbands and confederates over the following years. For example, the suggestion of prostitution is often implicit in cases involving the women, as is the frequenting of and location of disorderly spaces (inns, taverns and coffeehouses). ${ }^{19}$ Wilcox had been drinking with Mary Sullivan in John Eaton's coffeehouse, near Leicester Fields, when the alleged robbery took place. Clearly the women were engaged in a series of events that involved alcohol, seduction, and (alleged) theft. Moreover, their places of residence and the local networks to which they had recourse were in close proximity to areas such as Covent Garden and the Haymarket, long established as a centre for prostitution. Nevertheless, as Tony Henderson has argued, recourse to prostitution might be seen as one of a range of available sources of income available to plebeian women. ${ }^{20}$ Further problems are associated with the clients or victims. Thus in those cases where drunken men were robbed in disorderly public houses, the authorities seem to have been loath to bring in a guilty 
verdict, perhaps because of the complicity of the male prosecutor/victim in going willingly with the girls. In her study of the 'career' of Charlotte Walker, a prostitute operating in later eighteenth century London, Mary Clayton found that the lack of reliable evidence in the case of drunken prosecutors and witnesses, played a part in influencing Grand Jury decisions. ${ }^{21}$ Moreover, the victims may also have taken advantage of the reputation of the house, and the girls, to make accusations of theft.

The associations with prostitution and the proximity to Covent Garden was particularly significant by 1728 , when that area was to be increasingly targeted by both local residents and businessmen, and the authorities, in attempts to morally purge their streets. As Robert Shoemaker has shown, prosecutions were initiated by the Society for the Reformation of Manners throughout these years, using summary proceedings. ${ }^{22}$ The authorities preferred to use summary proceedings and periodic purges as a means of keeping the disorderly houses under control, since until the 1752 Disorderly Houses Act successful prosecutions of bawdy houses were often difficult to obtain. $^{23}$ Campaigns against disorderly houses were initiated in 1728 , and later in $1730-31 .^{24}$ Indeed, the Westminster Justices would petition the Secretary of State to provide financial support to protect constables who were the subject of essentially malicious prosecutions. ${ }^{25}$ These campaigns however, were not only the undertaking of overzealous religious reformers. Arguably the Society had become a handy vehicle for local people and active local justices who wanted to move out undesirable neighbours. ${ }^{26}$ I would suggest that the rhetoric 
of moral reformation was a very useful tool for putting known, troublesome, individuals out of action. As Shoemaker concluded of the judicial system in this context, 'the discretion it accorded to plaintiffs and justices allowed the law also to be used aggressively to see the punishment of adversaries... whose activities were not necessarily criminal' ${ }^{27}$ However, if we interpret the raids in the context of local tensions, the case study provided by the events described in this paper is revealing.

In the case of Moll Harvey, increasingly this strategy was to fail, and the authorities would turn to the indictment, and other means, to control her. If we look for reasons why Mary Harvey attracted more of the justice's attention than other women in her position it is probably best to remind ourselves of the attempts by the Westminster justices to arm their constables with the financial assurances of the crown. As we have seen in 1728, the Westminster justices had petitioned the Secretary of State in this regard. ${ }^{28}$ The following year, the house of Moll Harvey was raided. ${ }^{29}$ By this time she was based in Shugg Lane, close to her sister Isabella who kept the Crown Tavern, in Sherrard Street. ${ }^{30}$ In August 1729, it was reported in the British Journal or Censor, that some constables who had been to search Harvey's house, had been 'lock'd in by her, who charged 'em with the Watch, thereby hindering 'em in their Duty' ${ }^{31}$ On 9 October, Justice Cook committed Isabella Eaton to the Gatehouse prison upon the oath of three constables (James Body, and the Willis brothers), whom she had threatened to shoot in the heads at the Crown Tavern. She was also charged with keeping an ill-governed disorderly house. The same day, Moll 
was bound over by Justice John Ellis to await trial at the Westminster Sessions for keeping a disorderly house and for 'grossly abusing Justice Cook in his Office'. ${ }^{32}$ On Thursday 30 October, Bourke committed Moll to Newgate, 'for assaulting and wounding a Constable and his Assistants, in executing a Warrant for a Felony committed at the Crown Tavern in Sherrard Street, St. James'. Isabella Eaton was committed to New Prison to await further examination, on suspicion of robbing a gentleman in the tavern. ${ }^{33}$ These attacks on the constables need to be read with a caveat. The events may have originated in resisting arrest although through the lens of indictment and press report, they appeared as assaults, woundings and attacks. As Jennine HurlEamon points out, in a number of cases of violence directed against constables there is evidence of venality on the part of the constables. Thus constables 'manufactured' assaults, and later dropped the charges in exchange for payment. ${ }^{34}$ According to Hurl-Eamon, female participation in attacks on constables between 1680 and 1720 was low. Nevertheless, plebeian Londoners were vigilant against the constables overstepping their authority, suggesting that much of the violence was a result of resisting arrest, either by the accused or by the local community. ${ }^{35}$ By early November, both Moll and Isabella were committed to Newgate upon charges of felony. ${ }^{36}$ On Friday (21) the Daily Journal's London news was taken up with the account of the arrest of Mary Sullavan, 'a notorious Pick-pocket' in Southwark by a warrant drawn up by Justice Bourke. She was committed to the Gatehouse charged with being involved with Mary Harvey and privately stealing, 'from a Gentleman at the 
Standard Tavern in Leicester Fields, a Diamond Ring and a Silver gilt SnuffBox of a considerable value'. She was also charged (with Isabella Eaton) for the Crown Tavern robbery. ${ }^{37}$ At the Old Bailey Sessions in January 1730, Mary Sullivan and Isabella Eaton were tried on two indictments: first for the theft of the diamond ring and snuff box, from William Burroughs in the Standard Tavern in Leicester Fields on 16 October 1729; second for the theft of two Guineas from Henry Crew on 25 October $1729 .{ }^{38}$ The evidence in this case is convoluted, and even during the proceedings there is confusion over dates. Prosecution evidence was provided by John Davis and Mary West (alias Elizabeth Ryley), with Davis giving evidence to the effect that Sullivan and Eaton were involved in the theft. ${ }^{39}$ Mary Harvey gave evidence that Davis had accused her of stealing the ring, for which she had been committed to prison. In the second felony, Henry Crew was clearer in his evidence, although he admitted to having been drinking. In this case he was picked up by a woman (Anne Cragg, described by the prosecution as a 'Whore and a Thief') near Leicester Fields, and then went for a drink with her at the Crown Tavern. The woman was thrown out of the tavern by Mary Sullivan ('hussy, what do you do here? Get you gone') who then stayed to drink with Crew. After some more wine, Mary 'fell to playing at my Cod-piece', and at this point Crew realized he was being robbed. At this point Mary demanded the Reckoning ('G-d D-n you, pay your Reckoning, and get you out of the House'), which Crew could not pay since she had stolen his money. The next day he took out a warrant against Eaton (as the mistress of the house) and Sullivan. Mary West, a servant 
at the Crown Tavern, gave evidence for the prosecutor again, stating that Ann Cragg, Mary Sullivan and Isabella Eaton had shared the two guineas between them. ${ }^{40}$ Harvey gave evidence for the defence, stating that West was a thief, 'and made a long harangue about two Plates, and of her having Money for being an Evidence against the Prisoners'. Both women were acquitted. ${ }^{41}$ The third of the indictments that had originally been drawn against Eaton and Sullivan in early December 1729, was not tried until early April 1730. This was for the theft of a gold watch, and 28 guineas from a person unknown, an event that had apparently taken place at the Crown Tavern, in late October 1729. The women were acquitted. ${ }^{42}$

In 1730 there began a sequence of events that were to effectively keep Moll in some sort of custody for much of the next two years. In early July it was reported that the Westminster justices had granted a warrant against several people who 'frequented the house of Moll Harvey'. ${ }^{43}$ According to the reports, the constables who went to serve the warrants were beaten by Harvey and her husband; fresh warrants were granted and a number of Moll's 'Gang' (as they were now generally referred to), though not Moll, were sent to the Gatehouse. If we consider these events, alongside the previous confrontations with the constables, we can see that Moll Harvey and her associates did not take the arrival of the constables and the threat of the warrant lightly. The escalation into violent conflict, could be read as a householder protecting her home, rather than simply as a prostitute or disorderly housekeeper, or indeed, criminal offender, resisting arrest. Whilst the magistrates were keen to protect 
their constables from 'vexatious' and malicious prosecution, some of these prosecutions may have been justified. ${ }^{44}$ For example, during the summer of 1730 Thomas Willis was under indictment along with 'other informing constables' for assaulting a gentleman in Shoe-lane on 23 April. $^{45}$ The defendants were found guilty in December of that year, and the Willises all but disappeared from the historical record. ${ }^{46}$

\section{The 1730 Disorderly House Campaign}

In the spring and summer of 1730 the confrontational relationship between Harvey, Eaton and the brother constables, Thomas and Michael Willis, was central to events. ${ }^{47}$ Arguably it is at this point when local agendas and moral reformation politics more sharply coalesced. Clearly, the Westminster justices in the shape of Cook and Bourke had failed, despite their numerous attempts, to control or indeed, remove, Harvey and Eaton. With the entrance of Sir John Gonson (the Chairman of the Westminster Sessions), and the stepping up of the campaign, Mary Harvey’s fortunes were set to take a turn for the worse. ${ }^{48}$ The raids of 1730 were to be immortalized in The Harlots Progress. In plate 3 the prostitute, Moll Hackabout, is portrayed in the grip of steady decline in a Drury Lane garret. As Jenny Uglow describes it in her biography of Hogarth, 'This is the point of her second fall, from whoring to crime, as she swings the stolen watch from her fingers. And this too, is the moment of her legal fall - it is not a bold young lover but... Justice Gonson who steps thoughtfully through the door, finger to lips, followed by the watchmen with their wooden staves' ${ }^{49}$ The series was executed by Hogarth over the summer of 1730 . Clearly a keen 
observer of the daily news, the series contains allusions to several notorious criminals and bawds of the day. ${ }^{50}$ Dahboiwala suggests that the impact of these raids were limited, 'it was not accompanied by any major effort against streetwalking ${ }^{51}$ Arguably this is because the raids were less about moral reformation, and more about trying to tackle local social problems. ${ }^{52}$ Certainly, these social problems spread further a field than St. James's parish. In fact the initial meetings were responding to petitions by local tradesmen and respectable residents of St. Martin's in the Field, who were becoming increasingly intolerant of the behaviour of the inhabitants of the less salubrious parts of the neighbourhood of Drury Lane. ${ }^{53}$ By July, petitions had also been received from the residents of St. Paul's, Covent Garden complaining of the 'frequent outcrys in the night, fighting, robberies, and all sorts of debauchery committed by them all night long to the great inquietude of his majesties good subjects ${ }^{54}$ In response to this a Committee of Justices was set up in order to inquire into the problem. By mid-July petitions from neighbouring parishes had extended the raids to St. Margaret's, St. Anne's, St. John the Evangelist, St. George's in Hanover Square and St. James. ${ }^{55}$ The petitions, and the meetings they prompted, were also widely reported in the daily press. ${ }^{56}$ Arguably these petitions from residents enabled a more formal and organized campaign, spearheaded by Gonson. Certainly this series of raids were to continue throughout the rest of 1730 , until the early months of $1731 .^{57}$ According to a report into the raids, the Committee appointed to look into the complaints by local residents met at the vestry forty-two times. ${ }^{58}$ In this time 
they bound over forty-eight persons for keeping and maintaining disorderly houses; admitted to prison sixteen persons for keeping disorderly houses and ill-governed houses; and indicted twenty-four persons for keeping disorderly houses at the sessions for the City and Liberty of Westminster. Using the much discredited general warrants, resulted in the committal of 127 men and women to Tothill Fields house of correction, apprehended in disorderly houses or on the streets (the legality of the warrant had been confirmed and approved by the Court of King's Bench). ${ }^{59}$ Most of these were later discharged. The report singled out Mary Harvey and Isabella Eaton, 'That amongst the disorderly houses so suppressed one formerly kept by one Mary Harvey als Mackeige being the Blackmores head \& Sadlers arms in or near hedge lane \& also the house of Isabella Eaton als Gwyn being the Crown tavern in Sherrard Street St James were two of the most notorious for harbouring and entertaining Gangs of Thieves, pickpockets \& desperately wicked felons' ${ }^{60}$

As already noted, the Westminster Justice's had ensured that their constables were protected by writing to the Secretary of State. A response came from the Secretary of the State of the Northern Department, Lord Harrington. ${ }^{61}$ The letter congratulated Gonson upon the good work being done to suppress the disorderly houses, and confirmed the government's financial support for the activities of the Westminster Justices, and their constables: 'the Sollicitor of the Treasury is ordered to defend, at his Majestys Expence, the Constables and other Peace Officers, in any Actions or Suits that may be brought against any of them for what they shall do in the faithful Discharge of 
their Duty of their Offices, in putting in Execution the Warrants issued to them by the Justices of the Peace'. ${ }^{62}$ At the Sessions of the Peace for the City and Liberty of Westminster, which started on Monday 17 August 1730, John Gonson took the opportunity to explain the 'Nature, Design and most extensive Power' of the constables, all of whom had been ordered to attend the Court. ${ }^{63}$ At the same adjournment, and it would be nice to think at the point that Gonson was pontificating, Mary Harvey vocally made herself known. She was taken into custody for 'breeding a Disturbance in the Court, and abusing the Justices on the Bench'. Upon the attempts to take her into custody, Mary physically resisted: 'she beat them with such Violence, and so resolutely defended herself, that they could not get her out of Court for some time' ${ }^{64}$ On Thursday 20 August the Westminster justices met in the Vestry room of St. Paul's Covent Garden. ${ }^{65}$ Isabella Eaton attended the meeting in order to present a petition to the justices, who had charged Moll with contempt of court. The petition acknowledged Moll's insolent behaviour, and asked that she should be admitted to bail. In response the justices charged Moll with receiving stolen goods from Mary Sullivan. ${ }^{66}$ Harvey was charged with receiving a pair of diamond earrings 'knowing them to be stolen, and for insisting on 15 Guineas for restoring the same which is Death by a Statute of the $5^{\text {th }}$ of Queen Anne, upon which the late Jonathan Wilde was convicted' ${ }^{67}$ Whilst Harvey would not be tried on this indictment until October 1730 (when she was tried along with Mary Hall alias Stanley alias Sullivan and Isabel Eaton alias Gwin), on 28 August she was brought from the Gatehouse to the 
Old Bailey in order, 'to give Evidence against Michael and John Willis, upon the Indictment she preferred against them at the last Sessions for robbing her of 3 Gold Rings on the King's Highway in the Parish of St. James's, Westminster, the Willises having surrendered themselves on that Indictment'. ${ }^{68}$ In court she was described as being 'more modest then usual', although the press were at pains to point out that this was only because she had been threatened with confinement. The trial apparently lasted several hours and the Willises were 'honourably' acquitted. ${ }^{69}$ Whilst the press reported it as the trial of Michael and John Willis, it was in fact the trial of Michael and Thomas Willis (who as we know was already under indictment for his part in the attack on Charles Geery). ${ }^{70}$ The trial referred to the events of early autumn 1729, when the Willises and the parish constable James Body had taken up Isabella Eaton at her home as a result of complaints by various neighbours. ${ }^{71} \mathrm{~A}$ full-scale fight had ensued, initiated (according to the Willises) largely by Mary Harvey, whom 'attended by several people with Clubs' attempted to rescue her sister and in the process 'beat and abused' Michael Willis in a violent manner. In her evidence Harvey said that the Willises had assaulted her, kicked and punched her, snatched gold rings off her fingers, and generally caused an affray. The trial brought forth a number of witnesses on behalf of Harvey, including William Macheig (Harvey's common-law husband) and Isabel Gwyn (Eaton). This evidence suggests that the accused were well known as informers, but also described quite lurid levels of public violence, and a very public fight between Harvey and the two defendants. In their 
defence, the Willises protested that they had only been doing their duty as informers. Moreover, according to Michael Willis, this was personal, 'she has frequently threatened to be reveng'd on us; and that she had declar'd since the Indictment was found, that Robbery or no Robbery, she would hang me' ${ }^{72}$ James Body, the parish constable, deposed, 'That having taken up Mrs. Eaton by a Warrant, Mrs. Philips (Harvey) came with several Men with Mop-Staves and Broomsticks to rescue her Sister, and had in her Hand a Meat-Fork to stick the Persons who had her Sister'. The Willises were acquitted after calling a number of the Westminster magistrates to defend their reputations, including Justices Gonson, Railton, and De Veil (here spelt Du Val). The magistrates testified that the Willises had been 'very serviceable in suppressing the disorderly houses; and gave the Prosecutor the Character of a very turbulent and disorderly Woman, and one of the vilest of her sex' ${ }^{73}$ Mary Harvey was returned to the Gatehouse.

September was to be a particularly active month for Sir John Gonson, the Westminster justices and their constables. A number of arrests were made in Drury lane, and a number of women committed to the Tothill Fields Bridewell, including a number of women out of a 'house in Hedge-lane where Mary Harvey lately lived' on the night of the 24 September. ${ }^{74}$ Isabella Eaton was also charged and committed to Newgate, for involvement in the robbery of the diamond rings received by Harvey. Mary Sullivan had been committed by Justice Bourke sometime during the previous month. ${ }^{75}$ Finally, on the 14 October 1730 the three women came to trial at the Old Bailey for the robbery, 
and in the case of Harvey, receiving. ${ }^{76}$ This trial sounds suspiciously contrived, the evidence was imprecise to the point that the witnesses were not even able to specify the date of the robbery, stating it to have happened sometime in the last two to four months. Considering that Mary Harvey at least, was in prison for much of the previous two to four months, it is perhaps unsurprising that all the prisoners were acquitted. However, this did not amount to a release from custody, as by the end of that week, Harvey and Eaton were attempting to be admitted to bail on another indictment, for 'wilful and corrupt Perjury', against the Willises. ${ }^{77}$ On the morning of October 31 Mary Harvey was brought to the King's Bench Bar, through means of a Habeas Corpus directed to the keeper of the Gatehouse. ${ }^{78}$ It was not unusual for disorderly house keepers to have cases removed to higher courts in order to delay prosecution, which may explain the shift from the Middlesex Sessions to King's Bench in these events. Her Counsel argued that given that she had been confined in the Gatehouse for so long (since the 17 August that year), she should be bailed, with the proviso that she would undertake to appear at the next Westminster Quarter Sessions, and also to ask pardon 'of the Worshipful Bench for her rude and indecent Behaviour' ${ }^{79}$ However, the justices refused to show Harvey any mercy, and instead responded by confronting her with another three charges, indicting her twice for keeping a disorderly house, and once for beating a Constable. According to the Justices, since she had failed to appear and plead to the indictments her bail was forfeited. Clearly they were determined not to let Harvey escape their grasp this time and she was 
committed to the King's Bench prison until she found bail. ${ }^{80}$ After that she was to be remanded back to the Gatehouse until, 'she shall make such a Submission as the Chairman and the rest of the Justices of Westminster shall think proper to accept of, and until they shall think fit to discharge her ${ }^{81}$ Despite her predicament, the fact that Mary had recourse to legal counsel does tell us something about Mary's importance. Before the mid-1730s defendants on felony charges rarely had access to counsel except, in theory, to argue points of law. These were employed "only in doubtful, not in plain cases", in this instance presumably some doubt was evident in Mary's case. ${ }^{82}$ Moreover, she was not simply a 'disorderly' woman, but an innkeeper, and arguably a woman of some importance within her plebeian community. There are similar cases of 'disorderly' women using the writ of Habeas Corpus at this time. For example, Mary Freman, alias Talby (also Moll Freeman, alias Talboy), who challenged her commitment in November of 1730 was described as having five counsel, 'This creature is supported by several noted gamesters and sharpers about Covent-Garden' ${ }^{83}$

The friction between Mary's community and the Westminster justices was deepening by the autumn of 1730 , with continued meetings of what was now referred to as the Disorderly House Committee, and a series of warrants and commitments to Bridewell throughout November and December. On the 11 November Mary Sullivan was committed to the Gatehouse for two felonies (picking-pockets) and David Hamilton, described as one of Harvey's gang, was charged on warrant of detainer for involvement in one of the felonies. ${ }^{84}$ 
The Westminster justices were making sure they mopped up as many of Moll Harvey's 'Gang' as possible. ${ }^{85}$ In late November (25) Mary was given notice at the King's Bench Prison of her trial for perjury at the next Sessions of the Old Bailey. ${ }^{86}$ However, Moll was not moved to Newgate to await her trial since she was still awaiting trial at King's Bench. She was found guilty of keeping a disorderly house at the sitting of Nisi Prius of the King's Bench, on 3 December 1730 , but not sentenced at this point. ${ }^{87}$ Meanwhile, on 9

December Mary Sullivan came to trial for the theft of two guineas from John Richards. ${ }^{88}$ Isabella Eaton was also tried for the same felony. The evidence recorded at the Old Bailey, amounts to little more than a drunken tit-for-tat over the Reckoning at the Crown Tavern. The women were acquitted, but Isabella was to be removed to the Gatehouse, 'she being charg'd with diverse crimes by Justices of the Peace for the City and Liberty of Westminster'. ${ }^{89}$

\section{Moll Harvey at Large}

At this point, with both Harvey and Eaton in custody, awaiting their trial for perjury, Moll Harvey tired of trying to negotiate the justice system. ${ }^{90}$ On the morning of Wednesday 13 January 1731, Mary broke out of the King's Bench

Prison in Southwark, apparently taking several other prisoners with her. ${ }^{91}$ She was retaken 3 February in Holborn, and taken back to King's Bench Prison. ${ }^{92}$ The following week she finally went to King's Bench to receive her sentence, which was to 'stand in the Pillory at Charing Cross between the Hours of Twelve and Two, to pay one Mark Fine, to be imprison'd three Months, and to give Security for her good Behaviour for five Years'. She was also charged on 
a perjury indictment to which she pleaded not guilty. On the journey from King's Bench (held in Westminster Hall) to King's Bench Prison (in Southwark) Mary escaped again, near the door of the Fountain Alehouse (close to the court, in King's Street). ${ }^{93}$ That evening, four Irishmen were committed to Newgate by Justice De Veil, for helping Mary escape. ${ }^{94}$ According to the Grub Street Journal, she was retaken again on King's Street. The following Tuesday (16) the Daily Journal reported that she had been arraigned at the King's Bench on Friday (12) and that Isabella Eaton and the husband of Mary Harvey would be tried for the same offence. ${ }^{95}$ On Saturday 20 February, the London Journal noted that the previous Wednesday (17) one Richard White, an Irishman, 'one of the Persons concern'd in rescuing the famous Moll Harvey alias Mackeig' was committed to the Gatehouse by De Veil, to be prosecuted, together with the four other men who were in Newgate, by the Attorney General, at his Majesty’s expense. ${ }^{96}$

There is clearly some confusion in the newspapers around this time as to whether Moll Harvey was at large or not. It seems at some point after the 12 February she escaped yet again since she disappeared from the press record until 20 May, from which point several newspaper reported that she had been retaken on Monday night (17 May) at Wapping, 'in Bed with one Maccage, her pretended Husband ${ }^{97}$ On the front page of the Daily Post was the first report of what Mary had been doing in her absence. Harvey had apparently sailed to Rotterdam, with the intention of opening a tavern. However, the Dutch Government had been 'informed of her Exploits in England', and 
ordered Moll and her Sister (as Isabella seems to have escaped as well) to be put on the Black List. The Post reported that the consequence of this being a possible commitment to the Rasp-house, 'to work for seven or fifteen Years, or perhaps for Life', they decided to come back to England. ${ }^{98}$ On her return she 'lurked' around Wapping for some weeks, until she quarreled with one of her Gang, who 'out of Revenge discover'd her to the Constables'. She put up a fight upon arrest, 'so that they were forced to tie her Hands together, and with much Difficulty get her to Prison'. 99 A slightly more detailed account was provided by the Universal Spectator and Weekly Journal on Saturday 22 May, noting that Harvey's 'pretended husband' had been charged on Thursday (20) by warrant of detainer, and Isabella Eaton had been committed to New Prison the same day. ${ }^{100}$ On Monday 24 May Eaton and Mackeig were brought to King's Bench bar by writ of Habeas Corpus and committed to King's Bench Prison. ${ }^{101}$ According to the London Evening Post (25 May) and the Daily Journal (27 May) Moll Harvey was also supposed to have been brought to King's Bench on an Habeas Corpus. ${ }^{102}$ However, on either Sunday (23) or Monday (24) she managed to escape again by dressing in men's clothes, but was retaken on Monday or Tuesday afternoon, 'at a publick House in St. George's Fields'. ${ }^{103}$ In mid-June it was reported that Moll, and other of her ‘Accomplices' (including Isabella Eaton and William Mackeig) had broken out of New Prison. ${ }^{104}$ They were tried in their absence upon the perjury charge, at Guildhall Sittings of the King's Bench and found guilty. ${ }^{105}$ On Friday night, 25 June Mary and Isabella were found making a disturbance in St. Giles's, and 
returned to the New Gaol in Surrey where they were to stay until they received their judgment in the perjury case at King's Bench. ${ }^{106}$ From Friday 19 November, the case was being argued in King's Bench, and would not be resolved until the end of the month. The substance of the legal arguments about the case seem to have been over the specific nature of the indictment. Thus the three prisoners (Harvey, Eaton and William MacKeig) were found guilty on one indictment, but each one of them should have been indicted separately 'that the crimes were distinct and separate'. ${ }^{107}$ Eventually, on 27 November the judgment was reversed, and Isabella Eaton and William Mackeig were discharged. Mary Harvey was to return to court on Monday 29, as there were other charges against her. However, despite learned argument by Counsel, 'there not being sufficient Proof of them, the Court discharged her'. ${ }^{108}$ Given the range of indictments and informations which had been found against Mary Harvey during the previous year or more, its very tempting to conclude that these charges were spurious. As far as can be told, she was only found guilty of one of the charges, for keeping a disorderly house, for which she was found guilty at King's Bench in December 1730. On every other charge she was either acquitted, or in the case of the perjury case, the verdict was reversed. This points to the absolute determination of the Westminster justices to close down Moll Harvey's operation, and their willingness to use methods of dubious legality whilst at the same time working within the structures of the formal justice system. Moreover, it is likely that such cases were particularly difficult to try. Thus in the majority of the cases in which the 
women were involved, the prosecutors had been drinking, and the accusations of theft were made in the context of sexual congress, or the process of the 'reckoning'; in other words, at the point of financial transaction. The fact that it is unclear whether this 'reckoning' was for drinks or for more personal services arguably undermined the evidence of the prosecutor.

By the late summer of 1732 , the series of disorderly raids were almost over. Arguably, the Westminster justices had achieved what they had set out do by purging the most notorious disorderly houses. In the short-term this was a successful strategy. Disorderly women and men were fined, or sent to the House of Correction, and, if not reformed, hopefully stymied. In the longerterm, given the inability to permanently remove prostitution from areas like Drury Lane and the Haymarket, these campaigns arguably had a limited impact. ${ }^{109}$ Nevertheless, contemporaries regarded the campaigns as a success. In 1731, an anonymous publication attributed to Daniel Defoe dealt with the campaign against vice, singling out the Work of the magistrates of Westminster. ${ }^{110}$ The vigorous conduct of the Westminster justices, in 'attacking the Crowd of disorderly people' should set an example, 'for certainly the City and Liberties of Westminster (tho' bad enough) are not the only Places which want to be reformed; there are other Sinks of Wickedness which want cleaning, besides those in the Dominion of MOLL HARVEY'. ${ }^{111}$ In 1732, a satirical poem published in the Craftsman, apparently as a response to news about trained bands in Middlesex and Westminster, included the following verse: 'Nor does Sir John require your Aid, But wishes you would 
mind your Trade, Whist He alone can serve you; For by his own unwearied Pains, Sharpers and Whores He leads in Chains, And triumphs O'er Moll Harvey'. ${ }^{112}$ After her discharge in November 1731, Mary Harvey went to ground, or at least, the press had (for now) tired of her. On the hand, as we have already seen, they widely and extensively reported the case of Thomas Willis and three other informing constables for the assault on Charles Geery at King's Bench Bar. ${ }^{113}$ This spelt the end for the careers of the Willises as constables (at least in Middlesex and London). Arguably, despite being found innocent of the highway robbery charge in 1730 , the guilty verdict against Thomas and the publicity attracted by the perjury case had somewhat tarnished their reputation. Or it may be that since the Westminster justices had achieved their main aims by 1732 , and since the Reformation of Manners was on the wane, their services were no longer required. Indeed, whilst one publication contained a laudatory account of the Westminster justices campaign against the disorderly houses, it also described how the reforming societies had gone seriously awry, with accusations of scandal and bribes. At the root of this corruption were the constables: 'Among these are to be reckon'd Mercenary Watchmen, Hired Constables, and especially those they call the Reforming Constables; an officious pretending People, who, under the Appearance of Zeal for Reformation of Manners, have by Connivance, and more especially by notorious Bribery and Corruption...propagated that fatal Degeneracy of Manners, 114 


\section{Conclusion}

In conclusion it would be misleading to suggest that this is anything but an unusual case. Whilst there are parallels with similar cases of prostitutes and disorderly women who may have 'played the system' and taken advantage of unreliable evidence, Harvey's case is also distinct. ${ }^{115}$ Thus whilst Harvey's crimes are associated with prostitution, frequently they involve goods of a significant value, or directly relate to conflicts with authority. Indeed, Mary and Isabella are clearly well known to the justices, and the women have a 'public' reputation. I would argue that Moll Harvey's notoriety allows us a different way of thinking about the mechanisms of justice in the early eighteenth century. Whilst most accounts have necessarily focused on the administrative machinery and essentially the law enforcers perspective, the cases presented in this article, particularly as they deal with the same people over a substantial period of time, have enabled a number of insights into the grass-roots impact of the policing of the poor. Firstly, the events described in this article point to the importance of face-to-face relationships in criminal justice systems, and particularly in the early eighteenth century when the parish still predominated in local policing arrangements. The direct involvement of the magistracy, their interaction with the constables, the confrontations between the magistrates, the accused, and the broader community, underline the important role of this figure in pre-modern law enforcement. Indeed, from these cases we see that justice had a wide-range of tools to draw upon in the maintenance of local order. Thus the tools of 
criminal justice: the warrant, the indictment, the court-room, the lock-up, the prison, as well as the force and organization of civic bodies, in this case the Society for the Reformation of Manners were drawn upon in these attempts to curtail Moll Harvey's activities in their locality. Hence this article has demonstrated the importance of the Society for the Reformation of Manners as a local law enforcement body. The strong connection between vice and disorderly spaces which characterised much of the Society's propaganda, was a gift to local justices and local 'respectable' residents who were able to enforce control of disorder in their own back-yards cloaked in the rhetoric of national, moral reformation. The 1730 campaign effectively sought to kill two birds with one stone, to stymie Harvey and her confederates, and at the same time round up the usual disorderly suspects.

This article has also shown that, in this case, justice bit off rather more than it could chew. Thus the second strand of my argument has been to show how Mary Harvey was equally to take advantage of the flexibility and discretion inherent in the early eighteenth century system. Whilst this half of the story is much less visible it is significant that in the numerous trials that the women collected between them, guilty verdicts were rare. Moreover, in the King's Bench perjury trial, the verdict was reversed. Indeed, when the court addressed Isabella Eaton, who was appearing as a defense witness at the Old Bailey trial of Jane Murphey alias Macloughlane in 1732, she had a smart answer:

Court. Soams is your Name? How long have you gone by that Name? 
Isabella Eaton. About a 12 Month.

Court. I think I have try'd you here by another Name.

Eaton. Very like you might try me, my Lord, and by another Name too; but what if you did, I was Innocent, and my Jury acquitted me. I never came here for my Crimes, but my Passions. ${ }^{116}$

Whilst we have to be careful in how we use notions of agency (as can be seen by the women's fate below) this case provides an extensive example of plebeian Londoners interacting with, resisting to, and in some ways shaping justice. I would argue that it is necessary to look beyond the actions of Moll Harvey and her immediate circle, and consider the wider community and networks involved in this story. Thus reading between the lines of Moll Harvey's tumultuous life, we can glimpse disorderly, plebeian communities attempting to assert their place in the local community. As much as their disorderly pubs and taverns and nightly disturbances might have upset their respectable neighbours, the community resisted the constables, and 'bred disturbances' until local residents were forced to resort to the criminal justice system to purge their nuisance neighbours.

Moreover, despite the involvement of the Westminster justices, in the form of Gonson and latterly in the guise of the formidable Colonel Thomas De Veil, the women continued to maintain a presence (albeit a more subdued one) in the courts and in the press as witnesses and occasionally as the accused, for a while after these events. Mary Sullivan was to end her 'career' in July 1732, when she was found guilty of picking the pocket of George Anderson who had 
been drinking with Sullivan and Eaton in a pub in Drury Lane. ${ }^{117}$ She was transported to Virginia in October that year. ${ }^{118}$ Moll Harvey, after a short hiatus, reappeared at the Old Bailey, but was acquitted. By July 1732 she was up to her old tricks, accused of abusing a constable and keeping a disorderly house. The Grub Street Journal, in its version of the events published on 6 July, could not resist commenting, 'Either he was not a man, or she more than a woman ${ }^{119}$ She disappeared from the record by January 1733, except for a tantalizing reference in the Daily Courant, a year later: 'Dublin, Dec. 15. On Saturday last, the notorious Moll Harvey, so often mentioned in the English News Papers, was tried at the Thosel, and found guilty of picking the Pocket of one Mr. Morgan of seven Moidores, and was ordered for Transportation'. ${ }^{20}$ Isabella Eaton was to trouble the justices for a little longer. She appeared in the two trials already mentioned: alongside Mary Sullivan in July 1732, and as a witness in the trial of Jane Murphey in December that year. Isabella was rarely in evidence over the following five years, until the summer of 1735 when she was committed to Newgate for insulting and abusing Sir William Billers, the justice, in the execution of his office. ${ }^{121}$ This 'office' seems to have been in relation to the Willis case, for which Eaton and a woman described as her chambermaid, Elizabeth Walker, were accused of conspiracy. ${ }^{122}$ Isabella was tried in January 1736, at the General Quarter Sessions of the Peace at Guildhall, for the City of London, found guilty and sentenced to pay a $£ 5$ fine, spend a year in Newgate, and find securities for her good behaviour, for a year after that. ${ }^{123}$ By 1737 , Isabella was still in prison, petitioning for a release that 
was at least eight months overdue. ${ }^{124}$ Her last known brush with the law was in June 1738 , when she was committed to Newgate by justice De Veil, for picking a gentleman's pocket. During her long examination by De Veil, she had abused him 'prodigiously', threatened him and attempted to beat him. ${ }^{125}$ The following year, the Daily Post contained the following brief report on the front page of its edition for Friday 27 October 1738: 'On Monday last died in a Cellar in St. Giles's, the famous Isabella Eaton, who many times was committed to Newgate, and to most of the Gaols about Town. She died in a poor miserable Condition; a just Example to all such notorious Cheats'. ${ }^{126}$

\section{Conventions}

\section{CLRO Corporation of London Record Office}

LMA London Metropolitan Archives

OBSP Old Bailey Sessions Papers

TNA The National Archives

\footnotetext{
* Many thanks to Louise Jackson, Tim Hitchcock and Robert Shoemaker for reading earlier versions of this piece.

${ }^{1}$ D. Hay, 'Property, Authority and the Criminal Law', in D. Hay, P. Linebaugh, J. Rule, E. Thompson, C. Winslow (eds), Albions Fatal Tree: Crime and Society in Eighteenth-century England (London, 1975), 17 - 63, 25.

${ }^{2}$ P. King, 'Decision-Makers and Decision-Making in the English Criminal Law, 1750 - 1800', Historical Journal, 27 (1984), 27 - 54; J. Langbein, ‘Albion’s Fatal Flaws', Past and Present,
} 
98 (1983), 96 - 120; T. Green, Verdict According to Conscience: Perspectives on the English Trial Jury 1200 - 1800 (Chicago, 1985); J. Innes and J. Styles, 'The Crime Wave: Recent Writing on Crime and Criminal Justice in Eighteenth-Century England', The Journal of British Studies, XXV, 4, (1986), 380-435.

${ }^{3}$ P. King, Crime, Justice and Discretion in England, 1740 - 1820 (Oxford, 2000), 4.

${ }^{4}$ I refer here to the work of Peter Linebaugh, The London Hanged: Crime and Civil Society in the Eighteenth Century (London, 1991).

${ }^{5}$ King, Crime, Justice and Discretion; M. Clayton, 'The Life and Crimes of Charlotte Walker, Prostitute and Pickpocket', London Journal, 33/1 (2008), 3 - 19; T. Hitchcock, “'You Bitches...Die and be Damned": Gender, Authority and the Mob in St. Martin's Roundhouse Disaster of 1742', in T. Hitchcock and H. Shore (eds), The Streets of London: From the Great Fire to the Great Stink (London, 2003), 69 - 81. See also Gerald Howson's detailed study, Thief-taker General: The Rise and Fall of Jonathan Wild (London, 1970), although this account is hindered by the lack of full referencing.

${ }^{6}$ For critical discussion of this material see L. B. Faller, Turned to Account: The Forms and Functions of Criminal Biography in Late Seventeenth-and Early Eighteenth-Century England (Cambridge, 1987); H. Gladfelder, Criminality and Narrative in Eighteenth Century England: Beyond the Law (Baltimore, 2001); A. McKenzie, 'From True Confessions to True Reporting? The Decline and Fall of the Ordinary's Account', London Journal, XXX, 1 (2005), 55-70; idem., Tyburn's Martyrs: Execution in England 1675-1775 (London, 2007).

${ }^{7}$ H. Shore, “Undiscovered Country": Towards a History of the 'Criminal Underworld"'. Crimes and Misdemeanors: Deviance and the Law in Historical Perspective, 1, 1 (April 2007), 41-68.

${ }^{8}$ S. Devereaux, 'The City and the Sessions Paper: "Public Justice' in London, 1770-1800”, Journal of British Studies, XXXV (1996), 466-503; idem., 'The Fall of the Sessions Paper: Criminal Trial and the Popular Press in Late Eighteenth-Century London', Criminal Justice History XVIII (2002), 57-88; M. Harris, 'Trials and Criminal Biographies: A Case Study in Distribution', in R. Myers and M. Harris (eds), Sale and Distribution of Books from 1700 
(Oxford, 1982), 1-36.

${ }^{9}$ C. Emsley, T. Hitchcock and R. Shoemaker, 'The Value of the Proceedings as an Historical Source', http://www.oldbaileyonline.org/static/Value.jsp. For this article I have mostly relied on the electronic version of the Old Bailey Proceedings

(http://www.oldbaileyonline.org/index.jsp). Thus I will follow their citation system, including trial reference number for the Old Bailey trials.

${ }^{10}$ M. Harris, London Newspapers in the Age of Walpole: A Study of the Origins of the Modern English Press (London, 1987), 22.

${ }^{11}$ See J. H. Baker, 'Criminal Courts and Procedure at Common Law, 1550-1800', in J. S. Cockburn (ed.), Crime in England, 1550-1800 (London, 1977), 15-58.

${ }^{12}$ Old Bailey Proceedings (hereafter $O B P$ ), 6 December 1727, trial of Richard Savage, James Gregory, William Merchant (t17271206-24); LMA: MJ/SR/2494; MJ/SR/2497. S. Johnson, Life of Savage (London, 1744).

${ }^{13}$ LMA: MJ/SR/2497, folio 3.

${ }^{14} O B P, 28$ February 1728, trial of Mary Harvey, John Eaton, Arabella Eaton (t17280228-76); LMA: MJ/SR/2497.

${ }^{15} \mathrm{OBP}, 28$ February 1728, trial of Mary Harvey, John Eaton (t17280228-78); LMA:

MJ/SR/2498, folio 47.

${ }^{16} O B P, 6$ December 1727, trial of Henry Wilcox (t17271206-38); LMA: MJ/SR/2494. See also LMA: MJ/SP/1727, May, Instructions, etc. File - 3. Copies of commitments to New Prison, of Henry Willcox, for various causes. [no ref. or dates].

${ }^{17}$ Old Bailey Proceedings Punishment Summary 28 February, 1728. See also LMA: MJ/SP/1727, May, Instructions, etc. File - 3.

${ }^{18}$ OBP, February 1728, Mary Harvey, John Eaton (t17280228-78); LMA: MJ/SR/2498.

${ }^{19}$ The associations with prostitution in the case of Harvey and Eaton can also be seen in the case of Charlotte Walker in the late eighteenth century, although there are also significant differences. Charlotte stole mainly money in which case, the indictments were often 'not found'. She also stole on her own. Clayton, 'Charlotte Walker'. 
${ }^{20}$ A. Henderson, Disorderly Women in Eighteenth Century London: Prostitution and Control in the Metropolis, 1730-1830 (London, 1999), 16-18.

${ }^{21}$ Clayton, 'Charlotte Walker', 8-9.

${ }^{22}$ R. Shoemaker, Prosecution and Punishment: Petty Crime and the Law in London and Rural Middlesex, c. 1660 - 1725 (Cambridge, 1991), 245.

${ }^{23}$ Henderson, Disorderly, 93.

${ }^{24}$ See LMA: Middlesex Sessions, Orders of Court: WJ/OC/01, f. 127d (April 1728);

MJ/OC/003, f. 167.d (Dec. 1728); WJ/OC/002, ff. 101d-105d (April 1731).

${ }^{25}$ Shoemaker, Prosecution, 264. LMA: Middlesex Sessions, Orders of Court: WJ/OC/002, ff. 69d-70 (26 October 1728), 87-87d (July 1730), 89-89d (Aug. 1730); MJ/OC/003, f. 157d

(Nov. 1729); WJ/SP/1728, October.

${ }^{26}$ For a similar argument see R. Shoemaker, 'Reforming the City: The Reformation of Manners Campaign in London, 1690-1738', in L. Davison, T. Hitchcock, T. Keirn, R. Shoemaker (eds), Stilling the Grumbling Hive: The Response to Social and Economic Problems in England, 1689 - 1750 (Stroud, 1992), pp. 99 - 120. For co-operation between the SRMs and the Westminster Justices see T. B. Isaacs, 'Moral Crime, Moral Reform, and the State in Early Eighteenth Century England: A Study of Piety and Politics' (Ph.D, Rochester, 1979), 257.

${ }^{27}$ Shoemaker, Prosecution, 319.

${ }^{28}$ LMA: Middlesex Sessions, Orders of Court: WJ/OC/002, ff. 69d-70 (26 October, 1728).

${ }^{29}$ There is evidence that Mary was transported in March 1729, after being found guilty of stealing a silver snuff-box from David Wynn (OBP, 26 February 1729, trial of Mary Harvey (t17290226-37); LMA: MJ/SR/2516, folio 48; TNA: T53/345/418; P. W. Coldham, The Complete Book of Emigrants in Bondage, 1614 - 1775 (Baltimore, 1988), p. 394. If this Mary, given that we know that she was in London by the following August, she somehow managed to return from Annapolis. According to Ekirch, this is entirely feasible. He points out that there was a very quick turnaround for established criminals. A. Roger Ekirch, Bound for America: The Transportation of British Convicts to the Colonies, 1718-1775 (Oxford, 1987), 
97, 210-12, 220-222.

${ }^{30}$ Sherrard, or Sherwood Street, ran south of Golden Square, running into Shug Lane, which then ran into Piccadilly and the Haymarket.

${ }^{31}$ British Journal or Censor, 29 August 1729. Mary Salawen (Sullivan) was arrested in April 1729, but the bill was not found (LMA: MJ/SR/2518, folio. 65); In the same sessions there is an indictment for David Harvey (folio 66) and references to John and Arabella Eaton. David Harvey and Maria Harvey were next indicted in July 1729 (LMA: MJ/SR/2521). The women can also be traced through the Sessions Books over the course of 1729 in the volume for that year (LMA: MJ/SBB/B/0086).

${ }^{32}$ Daily Post, 10 October 1729; London Journal, 11 October 1729.

${ }^{33}$ Daily Journal, 1 November 1729.

${ }^{34}$ J. Hurl-Eamon, Gender and Petty Violence in London, 1680-1720 (Ohio, 2005), 99-100.

${ }^{35}$ Ibid., 98.

${ }^{36}$ Daily Journal, 4 November 1729.

${ }^{37}$ Daily Journal, 26 November 1729. See the Gaol Delivery records for December 1729, LMA: MJ/SR/2525, folio 41.

${ }^{38} O B P, 16$ January 1730, Trial of Mary Sullivan, Isabella Eaton (t17300116-19). The Sessions Peace roll for December 1729 is missing. However, the administration of the trials can partially be traced in the Gaol Delivery Rolls for the same month. LMA: MJ/SR/2525.

${ }^{39}$ LMA: MJ/SR/2525, Mary West als Ryley is mentioned on the wrapping of this roll as being 'committed...for being an evidence against Mary Sulavan als Stanley Mary Harvey als Phillips, Isabella Eaton also Gwinn, they being now in custody for several felonies by them committed...'

${ }^{40}$ LMA: MJ/SR/2525.

${ }^{41}$ Ibid. London Evening Post, 17 January 1730; Daily Journal, 19 January 1730.

${ }^{42} O B P, 8$ April 1730, trial of Mary Sullivan, Isabella Eaton (t17300408-26).

${ }^{43}$ British Journal, 4, 22 July 1730; Fogs Weekly Journal, 4 July 1730.

${ }^{44}$ For malicious prosecution against constables see Shoemaker, Prosecution, 264-5, and by 
constables see Hurl-Eamon, Gender, 99-100.

${ }^{45}$ London Evening Post, 14 May 1730; Daily Journal, 16 May 1730, An affadavit from Charles Ge(e)ry survives, TNA: KB 1/3/3. For the trial see The Country Journal or, the Craftesman, 11, 18 December 1731; Daily Journal, 13 December 1731; The Gentleman's Magazine, 11 December 1731. Also Looking Glass for Informing Constables; represented in the Tryals of JEREMY TOOLEY, WILLIAM ARCH, and JOHN CLAUSON (Soldiers) for the Murder of Mr. John Dent, Constable...(third edition)...to which is prefix'd The Proceedings at the Tryal of several Informing Constables before the Lord Raymond, December 11. 1731, who were all found Guilty of an Assault on Charles Geery, Esq. on April 23. In King's-Head Court, near Shoe-Lane (London, 1733). On Dent see Shoemaker, Prosecution, 180, 241, 261, 262.

${ }^{46}$ His death was reported in the London Evening Post, 10 November 1739.

${ }^{47}$ The Willises are clearly known to the magistrates and parish constables, and are described as constables in Old Bailey cases. It is not clear that they held formal office (their names were not found on the lists of constables in the sessions rolls). They are probably best described as 'informing constables'.

${ }^{48}$ Gonson was called to the bar of the Inner Temple 3 July 1715 ; knighted 14 May 1722 . He was at his peak in the 1720 s and early 1730 s. Whilst he continued as a JP for Westminster until 1765 his power seems to have waned with that of the SRMs. G. Lamoine (ed.), Charges to the Grand Jury, 1689-1803 (London, 1992), 25.

49 J. Uglow, Hogarth: A Life and a World (London, 1997), 202.

${ }^{50}$ Uglow suggests that Hogarth was at the very least ambivalent about the raids. Uglow, Hogarth, 193-7, 204-6, 209; Paulson, Hogarth: Vol. 1, 241-52

${ }^{51}$ F. Dabhoiwala, 'Prostitution and Police in London, c. 1660- c. 1760' (DPhil, Oxford, 1995), 191-2; idem, 'Sex and Societies for Moral Reform, 1688-1800', Journal of British Studies, XLVI, 2 (2007), 290-319.

${ }^{52}$ By 1730 the Society for the Reformation of Manners were in decline. According to Shoemaker this was in part due to the legal obstacles that interfered with the reformer's strategies for apprehending offenders, Prosecution, 265. 
${ }^{53}$ LMA: Order to Court: WJ/OC/2, ff. 85d - 86d (June, 1730)

${ }^{54}$ Ibid.

${ }^{55}$ LMA: Orders to Court: WJ/OC/2, folio 102.

${ }^{56}$ For example, the London Journal of Saturday 18 July 1730 gave a full account of the meetings. See earlier references in the Daily Journal, 16 May; London Journal, 23 May, 13 June, 18 July, 1 August, 8 August; Grub Street Journal, 23 July, 30 July, 6 August.

${ }^{57}$ For example, Daily Journal, 16, 23, 26 September, 11, 16, 18 November, 3, 19, 23, 29

December; Daily Post, 4, 24 September, 10 October, 5, 11 November, 17, 21, 27 December; Grub Street Journal, 7, 14 January.

${ }^{58}$ LMA: Orders to Court: WJ/OC/2, ff. 101d-105d.

${ }^{59}$ LMA: Orders to Court: WJ/OC/2, f. 103.

${ }^{60}$ LMA: Orders to Court: WJ/OC/2, ff. 101d-105d..

${ }^{61}$ LMA: Orders to Court: WJ/OC/2, ff. 89-90d.

${ }^{62}$ Ibid., Daily Journal, Saturday 18 August 1730.

${ }^{63}$ Daily Post, 18 August 1730; Daily Journal, 18 August 1730.

${ }^{64}$ Ibid.

${ }^{65}$ By this time the Westminster Justices were meeting twice a week mainly in the vestry room of St. Paul's, Covent Garden, or St. Martins. For example, London Journal, 1, 8, 29 August 1730; Grub Street Journal, 6 August 1730; Daily Journal, 21 August 1730; Daily Post, 25 August 1730.

${ }^{66}$ Daily Post, 21 August 1730.

${ }^{67}$ Universal Spectator and Weekly Journal, 22 August 1730.

${ }^{68} \mathrm{OBP}, 28$ August 1730, trial of Thomas Willis, Michael Willis (t17300828-76)). For the administration of the trial see LMA: MJ/SR/2537, folio 66, Maria Phillips (alias Harvey), William McCage and Maria Johnson (an alias of Mary Sullivan's) are named on the back of the indictment; Evening Post, 29 August 1730; Daily Journal, 31 August 1730. Eaton was not charged until 14 September 1730 (Evening Post, 15 September 1730; LMA: MJ/SR/2543, folio 60). 
${ }^{69}$ Evening Post, 29 August 1730.

${ }^{70}$ At the trial Mary Harvey in her evidence refers to 'Thomas Willis, who now says his name is John' (OBP, 28 August 1730, Thomas Willis, Michael Willis (t17300828-76)). In the indictment he is named as Thomas Willis (LMA: MJ/SR/2537, folio 66).

${ }^{71} O B P$, August 1730, Thomas Willis, Michael Willis (t17300828-76). Witnesses testify that the events took place on Lords Mayor Day, according to a witness named James Devins, this was the $28^{\text {th }}$ or $29^{\text {th }}$ September. From 1751 Lord's Mayor Day took place on 9 November, however it seems to have been movable before this.

${ }^{72}$ Ibid.

${ }^{73}$ Ibid. See also, Daily Journal, 31 August 1730; Grub Street Journal, 3 September 1730.

${ }^{74}$ For example, Daily Journal, 1, 23, 26 September 1730 (the latter for the reference to Hedge Lane); Daily Post, 4, 5, 16 September 1730; London Journal, 5 September 1730; Grub Street Journal, 10, 17, 24 September 1730.

${ }^{75} \mathrm{LMA} / \mathrm{MJ} / \mathrm{SR} / 2543$, 'Mary Sullavan' is named on the wrapping of the Sessions Roll.

${ }^{76} \mathrm{OBP}, 14$ October 1730, trial of Mary Hall, Mary Harvey, Isabel Eaton (t17301014-70); LMA: MJ/SR/2543, folio 60.

${ }^{77}$ Evening Post, 17 October 1730; London Evening Post, 31 October 1730. See the Sessions Roll for December 1730 (LMA: MJ/SR/2545, folio 53). This include an indictment for Maria Sullivan als Hall als Stanley; Isabella Eaton als Gwin.

${ }^{78}$ There are several forms of the Habeas Corpus writ. The more well-known writ was used in cases of illegal imprisonment, but there was also an Habeas Corpus writ which was used to remove people from one jurisdiction to another, or to bring them up to testify. It is unclear which form of the writ is being used in Mary Harvey's case. My thanks to Ruth Paley who explained this issue. Unfortunately, the affidavits for the terms in which Mary Harvey first appeared at the King's Bench are missing (TNA: KB1 3/2/12, 4 Geo. II Mich. 1730; 4 Geo. II Hil. 1730/31). A search of the other terms through 1731-2 (TNA: KB 1/3/2 and KB $1 / 3 / 3$, and KB2/1 'Miscellaneous affidavits 1727-37) drew a blank. Moreover, there are no King's Bench prison records for this period. Maria Harvey als Philips, Willus Harvey, Isabella Eaton (also 
listed as Gwin) can be found in the indexes to London and Middlesex defendants (TNA: IND 1/6672). The case is also cited in the English Reports, 'Anonymous [IN THE COURT OF KING'S BENCH]' Barn. K. B. 371 (1744).

${ }^{79}$ Daily Post, 2 November 1730; Daily Journal, 2 November 1730.

${ }^{80}$ King’s Bench Prison was in Southwark, off Borough.

${ }^{81}$ Daily Journal, 2 November 1730; Daily Post, 3 November 1730.

${ }^{82}$ Foster, Hale MS, cited by J. Langbein, The Origins of Adversary Criminal Trial (Oxford, 2003), 300, more generally on defense counsel, 106-7, passim.

${ }^{83}$ Daily Journal, 28 November 1730; Grub Street Journal, 3 December 1730. This writ is referred to in the Report discussed above (LMA: WJ/OC/2, ff. 101d-105d), in the context of accusations about the legality of the warrants, f. 103.

${ }^{84}$ Daily Post, 13 November 1730.

${ }^{85} \mathrm{LMA}: \mathrm{MJ} / \mathrm{SR} / 2545$.

${ }^{86}$ Daily Journal, 27 November 1730.

${ }^{87}$ Daily Journal, 5 December 1730.

${ }^{88} \mathrm{OBP}, 4$ December 1730, trial of Mary Sullivan, Isabella Gwyn (t17301204-72). Daily

Journal, 9 December 1730. See LMA: MJ/SR/2545, folio 53.

${ }^{89}$ Daily Journal, 10 December 1730. An indictment survives for Isabella Gwin als Hambledon in the Sessions Roll for January 1731, LMA: MJ/SR/2547, folio 32.

${ }^{90}$ Daily Journal, 31 December 1730

${ }^{91}$ London Evening Post, 14 January 1731; Daily Journal, 15 January 1731.

${ }^{92}$ London Evening Post, 6 February 1731; Daily Journal, 8 February 1731: Daily Post, 8 February 1731.

${ }^{93}$ King's Street was a main thoroughfare near to Westminster Hall. In other sources the Fountain is described as being in Tothill Street. London Evening Post, 11 February 1731;

Daily Post, 13 February 1731.

${ }^{94}$ Daily Journal, 15 February 1731; Grub Street Journal, 18 February 1731.

${ }^{95}$ Daily Journal, 16 February 1731; also reported in Daily Courant, 12 February 1731, Daily 
Journal, 13 February 1731, British Journal or The Traveller, 20 February 1731.

${ }^{96}$ London Journal, 20 February 1731. Also see reports in Reads Weekly Journal or British

Gazetter, 20 February 1731, Fog's Weekly Journal, 20 February 1731, Grub Street Journal, 1

April 1731.

${ }^{97}$ Daily Courant, 20 May 1731; Daily Journal, 20 May 1731; Daily Post, 20 May 1731;

Country Journal or The Craftesman, 22 May 1731; Fogs Weekly Journal, 22 May 1731;

Reads Weekly Journal or British Gazetter, 22 May 1731; Universal Spectator and Weekly

Journal, 22 May 1731.

${ }^{98}$ P. Spierenburg, The Prison Experience: Disciplinary Institutions and Their Inmates in Early Modern Europe (New Brunswick, 1991).

${ }^{99}$ Daily Post, 20 May 1731.

${ }^{100}$ Universal Spectator and Weekly Journal, 22 May 1731. Mackeig’s committal was also noted by the Daily Advertiser, 21 May 1731 and Mackeig's and Eaton's committals in the Daily Courant, 21 May 1731.

${ }^{101}$ London Evening Post, 25 May 1731; Daily Journal, 27 May 1731; TNA: IND 1/6672.

102 Ibid.

${ }^{103}$ Daily Courant, 26 May 1731; Daily Journal, 27 May 1731.

${ }^{104}$ London Evening Post, 15 June 1731; Daily Journal, 17 June 1731, London Evening Post, 19 June 1731.

${ }^{105}$ Either on Friday 18 or Monday 21 May. London Evening Post, 19 June 1731, Daily Journal, 22 June 1731.

${ }^{106}$ London Evening Post, 26 May 1731; Grub Street Journal, 1 July 1731.

${ }^{107}$ The debates between the Counsel can be traced through the press in November: London Evening Post, 20 November 1731, Fogs Weekly Journal, 20 November 1731, Daily Post, 23, 26 November 1731, Daily Journal, 25 November 1731, Daily Advertiser, 26 November 1731. ${ }^{108}$ London Evening Post, 27 November 1731; Daily Journal, 29 November 1731.

${ }^{109}$ For example, Hedge Lane, one of the locations with which Mary Harvey is connected, was still associated with prostitution in 1750 (see $O B P, 28$ February 1750, trial of Mary Maschal 
(t17500228-40)) and 1770 (see John Fielding's evidence in 'Committee to Enquire into the Several Burglaries and Robberies', Commons Journal, 1770, vol. XXXII, 881. See also Henderson, Disorderly Women, 50, 7.

${ }^{110}$ Defoe (attrib.), An Effectual Scheme for the Immediate Preventing of Street Robberies

(London, 1731). Also P. N. Furbank \& W. R. Owens, Defoe de-attributions: a critique of J.R.

Moore's checklist (London, 1994).

${ }^{111}$ Defoe, An Effectual Scheme, pp. 60, 61-2.

${ }^{112}$ The Craftsman, No. 316, 22 July 1732, 186.

${ }^{113}$ Gentleman's Magazine, 11 December 1731; Daily Journal, 13 December 1731; The

Country Journal or The Craftesman, 18 December 1731.

${ }^{114}$ Defoe (attrib.), Effectual Scheme, 14, 24.

${ }^{115}$ Clayton, 'Charlotte Walker'.

${ }^{116}$ OBP, 6 December 1732, trial of Jane Murphey (t17321206-38). See also Ordinary's

Account, 29 January 1733.

${ }^{117}$ OBP, 5 July 1732, trial of Mary Sullivan (t17320705-12); LMA: MJ/SR/2578, folio 19 . Her sentence of transportation is also recorded on the indictment. For Isabella Eaton see $\mathrm{MJ} / \mathrm{SR} / 2579$, folio 37 .

118 'Felons transported from London to Virginia by the Caesar, Capt. William Loney, in October 1732', 'Middlesex: Sullivan als Johnson', TNA: T53/36/423. See Coldham, Emigrants, 833.

${ }^{119}$ Grub Street Journal, 6 July 1732; LMA: MJ/SR/2577, folio 51.

${ }^{120}$ Daily Courant, 22 December 1733. She is not on Coldham's lists of Irish Transported Felons under any of her alias's, although he notes the paucity of the Irish Records. Coldham, Emigrants, 975.

${ }^{121}$ General Evening Post, 31 July 1735; Grub Street Journal, 7 August 1735. A Mary and John Eaton are named in the calendars for the Sessions Peace for August 1735, LMA:

$\mathrm{MJ} / \mathrm{SR} / 2640$, folio 28.

${ }^{122}$ London Evening Post, 31 July 1735. OBP, 10 December 1735, trial of Elizabeth Walker 
(t17351210-74).

${ }^{123}$ London Evening Post, 17 January 1736. See also Daily Gazetter, 17 December 1735.

${ }^{124}$ CLRO: CLA/047/LJ/13/1737/010, Petitions of Isabella Eaton, condemned to 12 months in prison in Jan 1736, at least 8 months overdue for release. n.d.

${ }^{125}$ London Evening Post, 20 June 1738; Daily Post, 22 June 1738; Reads Weekly Journal or British Gazetter, 24 June 1738; Old Common Sense or The Englishman's Journal, 1 July 1738; Daily Gazetter, 22 June 1738. The indictment survives in LMA: MJ/SR/2700, folio 39, however it was 'not found'.

${ }^{126}$ Daily Post, 27 October 1738. 